\title{
Tabularia
}

\section{Five charters concerning the early history of the chapter at Avranches : an edition revisited}

Cinq chartes au sujet de l'histoire des débuts du chapitre à Avranches: retour sur une édition

\section{Richard Allen}

\section{(2) OpenEdition}

\section{Journals}

Electronic version

URL: http://journals.openedition.org/tabularia/2554

DOI: 10.4000/tabularia.2554

ISSN: 1630-7364

Publisher:

CRAHAM - Centre Michel de Boüard, Presses universitaires de Caen

Electronic reference

Richard Allen, «Five charters concerning the early history of the chapter at Avranches : an edition revisited ", Tabularia [Online], Sources en ligne, Online since 03 December 2010, connection on 19 April 2019. URL : http://journals.openedition.org/tabularia/2554 ; DOI : 10.4000/tabularia.2554 


\title{
Five charters concerning the early history of the chapter at Avranches: an edition revisited ${ }^{1}$
}

\section{Cinq chartes au sujet de l'histoire des débuts du chapitre à Avranches: retour sur une édition}

\author{
Richard ALLEN \\ St John's College, Oxford \\ richard.allen@sjc.ox.ac.uk
}

The recent opportunity to re-examine the Livre vert of the cathedral of Avranches, which was the source of the five charters edited in the above-named article $^{2}$, led to the discovery of a number of typographical and transcriptional errors that had been overlooked prior to publication. Combined with the many mistakes of the cartulary scribe, which, except in cases of misspelling, were originally uncorrected, these errors left the texts as first published as very difficult documents to use. The new editions below are therefore offered as a replacement, and include corrections not only to the editor's own mistakes, but also to those of the medieval scribe.

It also became apparent in the course of this re-examination that the second of the five charters was not issued by Richard de Subligny, bishop of Avranches, as originally argued, but rather by his predecessor Richard de Beaufou. All references to the "confirmation", "act" or "charter" of Richard de Subligny should therefore be amended accordingly. This change does not affect the general arguments made in the original article, and it perhaps partly reinforces the idea that the cathedral chapter sought confirmation of the deanship following the Angevin capture of Avranches (see pp. 9-10). This would place the issuance of the first three acts in early 1142.

Finally, given the extent of the changes to the texts of the charters noted below, it has also seemed prudent to improve, where necessary, parts of the main body of the article. The page and line numbers in the following addenda et corrigenda refer to the PDF version of the article.

1. I am grateful to Dr Kathrin Korn for her comments on certain elements of these charters. Any errors that remain are my own.

2. R. Allen, "Five charters concerning the early history of the chapter at Avranches", Tabularia "Documents", 8, 2008, p. 1-33.

Tabularia "Documents", $\mathrm{n}^{\circ}$ 10, 2010, p. 37-44, 3 décembre 2010 http://www.unicaen.fr/mrsh/craham/revue/tabularia/print.php?dossier=sources\&file=11allen.xml 
p. 3 line 9: for "the eleventh or twelfth centuries" read "for the eleventh or early twelfth centuries". To the note add the following: "A large number of original charters issued by the twelfth-century bishops of Avranches in favour of the abbeys of Savigny and Mortain can be found at the Archives nationales in Paris, L 967 to 979. Only two, however, date from before 1150."

p. 8 lines 24-25: for "in which he and the dean Richard de Subligny record" read "in which he records"

\section{New editions :}

\section{1 - First confirmation by Hugh of Amiens, archbishop of Rouen, of the foundation of the deanship of Avranches ${ }^{3}$}

A. Original lost.

B. Bibl. mun. d'Avranches, ms 206, fol. $8 \mathrm{v}-9^{4}, \mathrm{n}^{\circ}$ XXIII, under the rubric: "Ordinatio super decanatu ecclesie Abr(incensis)".

Ptd. Lebrun, "Le temporel [diplôme]...", p. 14; Le Héricher, Avranchin monumental..., i, p. 178-179 (partial transcription).

Ind. Desroches, “Annales religieuses...”, i, p. 428-429; Desroches, "Sur les paroisses...”, p. 49; Le Héricher, Avranchin monumental..., i, p. 178-179; Spear, The personnel..., p. 6.

Note. This charter is dated by the episcopate of Richard de Beaufou. Since the confirmations of the bishops of Coutances and Dol that follow were probably made at the same time, they are dated from $1203 \times 1231$, i.e. the episcopal dates of John (VI) de Lysenach.

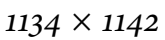

B

Hugo Dei gratia Rothom(agensis) archiepiscopus, karissimis filiis Ricardo episcopo $^{5}$, Ric(ardo) decano ${ }^{6}$, arch(idiaconis), et capitulo Abrinc(ensis) ecclesie, salutem, graciam et benedictionem. Quod ad dignitatem et incrementum sancte Matris Ecclesie pertinere dignoscitur a pastoribus et rectoribus ejus devota debet caritate suscipi et effectui mancipari, verumptamen quod a pie recordationis episcopo nostro Turgisio ${ }^{7}$ provide statutum est et, post communi

3. Each of the following charters contain black pen-decorated initials, which appear to be the work of the same scribe responsible for the main body of text. These are not noted in the editions below. A rubricator has filled the letter "E-" of "Ego" with red for each of the witnesses in act $n^{\circ} 3$.

4. The following note, written in a later hand (s. xiv/s. xv), is found in the margin below the second column of folio 8v: "Institucio decani. Item de eodem XXVI' folio sequenti et de annexione prebende decanatui”.

5. Richard de Beaufou, bishop of Avranches, 1134-1142.

6. Richard de Subligny, dean of Avranches, ?-1142/3.

7. Turgis, bishop of Avranches, 1094-1134. 
assensu capituli nostri, litteris et attestatione patris nostri Ricardi, de decanatu ecclesie nostre ${ }^{8}$ canonice confirmatum, auctoritate metropolitana decernimus annuere et imperpetuum ecclesie nostre ${ }^{9}$ et nobis ${ }^{10}$ firmius corroborare. Sicut enim a prefatis episcopis hoc ipsum confirmatum et cartis corroboratum est, ista ${ }^{11}$ precipimus, nostra qua preminemus auctoritate, in posterum observari et nulla varietate violari, hec igitur ecclesie nostre ${ }^{12}$ et nobis ${ }^{13}$ sit pax et reliqua. Ricardus Dei gratia Abrinc(ensis) episcopus successoribus suis episcopis in perpetuum. Nos itaque Ricardus ${ }^{14}$ de Suligneio, ingenuo siquidem et magne frugillitatis ${ }^{15}$ nec minoris spe ${ }^{16}$ miro ${ }^{17}$, decanatum in honorem ecclesie nostre ab illustri et pie recordationis episcopo Turgisio, cui $\mathrm{de}^{18}$ auctore suocessimus ${ }^{19}$, institutum concessimus et, presentis nostri pagina scripti, assensu capituli nostri, firma stabilitate confirmamus. $\mathrm{Ex}^{20}$, ut hujus decanatus institutio firmius stet inperpetuum, nostri sigilli impressione communimus et episcopali auctoritate roboramus. Si quis autem hanc nostri predecessoris, et cetera. Sunt autem decanatui hec aplicata: ecclesia de Veim ${ }^{21}$, et census cimiterii, et decime trium vavassorum in Veim scilicet W(i)ll(elm)i et Rog(er)i et filiorum Gir(ardi), et masura cujusdam ${ }^{22}$ Gir (ardi) ${ }^{23}$ cum decima; de abbate Montis, una pellicia grissata ${ }^{24}$ ad mensuram suppellicii ${ }^{25}$; decima de propriis vineis episcopi de campo Bostri; in manerio Sancti Philiberti ${ }^{26}$, decima de molendinis de Livet $^{27}$, et de Accurso $^{28}$, et de Tolwio ${ }^{29}$, et decima nundine, et decima census manerii. Quibus ipse Ricardus adjecit decimam de Choeio ${ }^{30}$ que est de feodo fratris sui cum ejus concessione. + Ego, Ric(ardus) episcopus propria manu scripsi. Ego

8. Sic B, corr. vestre.

9. Sic B, corr. vestre.

10. Sic B, corr. vobis.

11. Sic B, corr. ita.

12. Sic B, corr. vestre.

13. Sic B, corr. vobis.

14. Sic B, corr. Ricardo.

15. Sic B, corr. frugalitatis.

16. Sic B, corr. spei.

17. Sic B, corr. viro.

18. Sic B, corr. Deo.

19. Sic B, corr. successimus.

20. Sic B, corr. Et.

21. Vains, dép. Manche, cant. Avranches.

22. Sic B, corr. ejusdem.

23. These three individuals cannot be identified any more precisely.

24. Sic B, corr. grisia.

25. Sic B, corr. superlicii.

26. Saint-Philbert-sur-Risle, dép. Eure, cant. Montfort-sur-Risle.

27. Livet-sur-Authou, dép. Eure, cant. Brionne.

28. An unidentified place-name, probably located within Pont-Authou, dép. Eure, cant. Montfortsur-Risle.

29. Probably to be identified with the place Touvée or Touvoie, which was situated within PontAuthou.

30. Probably to be identified with the land called Toeio/ Toi (texts $\mathrm{n}^{\circ} \mathbf{2}$ and 5), which was located within Subligny, dép. Manche, cant. La Haye-Pesnel. 
Hugo Dei permissione Constanc(iensis) episcopus ${ }^{31}$, auditis super hoc autenticis instrumentis Abrinc(ensis) ecclesie et diligenter inspectis, que in presenti pagina verbo ad verbum fideliter transcripta sunt presentem paginam sigilli mei testimonio dignum duxi communire. Similiter nos, Joh(anne)s episcopus ${ }^{32}$ et capitulum Dolen(sis) ecclesie ipsa originalia cum sigillis, verbo ad verbum fideliter hic transcripta, diligenter inspeximus et audivimus, ad testimonium hujus veritatis sigilla nostra facientes apponi.

\section{2 - Confirmation of the foundation of the deanship of Avranches by Richard de Beaufou, bishop of Avranches}

\section{A. Original lost.}

B. Bibl. mun. d'Avranches, ms 206, fol. $33 \mathrm{v}-34^{33}, \mathrm{n}^{\circ}$ XXXIX, under the rubric: "Confirmatio Hug(onis) arch(iepiscopus) Rothom(agensis) super decanatu ecclesie Abr(incensis)" ${ }^{34}$.

Ptd. Lebrun, "Le temporel [diplôme]...", p. 61.

Note. This charter is dated by the episcopate of Richard de Beaufou.

$1134 \times 1142$

$\mathrm{B}$

Ricardus mis(eratione) divina Abr(incensis) episcopus, successoribus suis imperpetuum episcopis. Sancta et universalis Mater Ecclesia, bone spei filios brachiis pie dilectionis arcius amplectitur et diligencius in gremio suo fovet et uberius de proprio lactat ubere. Nos itaque Ricardo de Suligneio, ingenuo siquidem et magne frugalitatis nec minoris spei viro, decanatum in honorem nostre ecclesie ab illustri et sancte recordationis episcopo Turgigio ${ }^{35}$, cui Deo auctore successimus, institutum, concessimus et presentis nostri pagina scripti, assensu capituli nostri, firma stabilitate confirmamus et, ut hujus decanatus institutio firmus stet imperpetuum, nostri sigilli impressione communimus et episcopali auctoritate corroboramus. Si quis vero hanc predecessoris nostri et nostram institutionem ausu temerario scienter infringere seu diminuere temptaverit, canonice commonitus nisi correxerit bonorum apostolorum Petri et Pauli atque Andree indignationem incurrat, et anathema maranatha si perseveraverit sustineat. Conservantibus autem pacem datis, et ad augmentum bonorum conferentibus sit pax et felicitas perpetua. Amen. Sunt autem hec

31. Hugh de Morville, bishop of Coutances, 1208-1238.

32. John (VI) de Lysenach, bishop of Dol, 1203-1231.

33. The following note, written in a later hand (s. xiv/s. xv), is found in the margin above the second column of folio 33v: "Confirmatio decanatus Abrin(censis) facta per Richardu(m) episcopum Abr(incensem), quem decanatum Turgisius episcopus Abr(incensis) primus instituerat".

34. Sic $\mathrm{B}$, this rubrication belongs with text $\mathrm{n}^{\circ} 3$. For the identification of the majority of place and personal names within this charter, see the notes for text $n^{\circ} 1$.

35. Sic B, corr. Turgio. 
decanatui aplicata: ecclesiam ${ }^{36}$ de $\operatorname{Veim}^{37}$, scilicet Vib(er)ti et Rog(er)i et filiorum Gir(ardi), et masura ejusdem Gir(ardi) cum decim ${ }^{38}$; de abbate Montis, una pellicia grisia ad mensuram superlicii; decima de propriis decimis ${ }^{39}$ episcopi de campo Botri; in manerio Sancti Philib(er)ti, decima de molendinis de Livet, et de Accurso, et de Tolweio, et decima nundine, et decima census manerii. Quibus ipse Ric(ardus) adjecit decimam de Toeio que est ex feodo fratris sui cum ejus concessione. + Ego Ric(ardus) episcopus propria manu [scripsi].

\section{3 - Second confirmation by Hugh of Amiens, archbishop of Rouen, of the foundation of the deanship of Avranches}

A. Original lost.

B. Bibl. mun. d'Avranches, ms 206, fol. $34-\mathrm{v}^{40}, \mathrm{n}^{\circ} \mathrm{XL}$, under the rubric: "Confirmatio R(icardi) episcopi super decanatu ecclesie Abr(incensis)" ${ }^{41}$.

Ptd. Lebrun, "Le temporel [diplôme]...", p. 61-62.

Ind. Gazeau, Normannia monastica... , ii, p. 89, 217, 255.

Note. This charter was most likely issued in the months following the capture of Avranches by the count of Anjou in 1142. Strictly speaking, however, it should be broadly dated aft. 12 June $1141 \times 25$ April 1142, i.e. between the first appearance of Fraternus, abbot of Saint-Ouen, and the death of the bishop of Avranches.

\section{c. 1142 \\ $\mathrm{B}$}

Hugo Dei gratia Rothom(agensis) archiepiscopus, karisimis ${ }^{42}$ filiis suis Ric(ardo) episcopo, Ric(ardo) decano, archidiaconis et capitulo Abr(incensi), salutem in Domino, graciam et benedictionem. Quod ad dignitatem et incrementum sancte Matris Ecclesie pertinere dignoscitur a pastoribus et rectoribus ejus devota debet caritate suscipi et effectui mancipari, verumptamen quod a pie recordationis episcopo nostro Turgigisio ${ }^{43}$ provide statutum est et, post communi assensu capituli nostri, litteris et attestationibus patris nostri Ric(ardi)

36. Sic B, corr. ecclesia.

37. Either the cartulary scribe, or the text from which he worked, omitted here the phrase "et census cimiterii, et decime trium vavassorum in Veim", which is found in the same section of text $\mathrm{n}^{\circ} 1$.

38. Sic B, corr. decima.

39. Sic B, corr. vineis.

40. The following note, written in a later hand (s. xiv/s. xv), is found in the margin above the first column of folio 34: "Nota de fructibus decanatus presenti folio et sequenti. Item annexio prebende secundo folio sequenti. Item de eodem XXVI ${ }^{\circ}$ folio precedenti". The following note, written in the same hand, is found in the margin above the second column of folio 34 : "Confirmatio decanatus ecclesie Abrin(censis) per Hugonem archiepiscopum Rothom(agensem)".

41. Sic $\mathrm{B}$, this rubrication belongs with text $\mathrm{n}^{\circ} 2$.

42. Sic B, corr. karissimis.

43. Sic B, corr. Turgisio. 
episcopi, et ${ }^{44}$ decanatu ecclesie nostre ${ }^{45}$ canonice confirmatum, auctoritate metropolitana decernimus annuere et imperpetuum ecclesie nostre ${ }^{46}$ et vobis firmius corroborare. Sicut enim a prefatis episcopis hoc ipsum confirmatum et cartis corroboratum est, ita precipimus, nostra qua preminemus auctoritate, in posterum observari et nulla varietate violari, hec igitur ecclesie nostre ${ }^{47}$ et vobis multa servantibus sit pax Domini nostri Jhesu Christi. Amen. Quisquis vero contra hanc nostre constitutionis paginam scienter venire temptaverit, nisi pie que incepit corrigere procuraverit, sciat se anathemati subiciendur et gravi jactura plectandum.

Ego Hugo Rothom(agensis) archiepiscopus

Ego Ric(ardus) Abrinc(ensis) episcopus

Ego Arnulphus Lex(oviensis) episcopus ${ }^{48}$

Ego Valeranus decanus Roth(omagensis) ecclesie ${ }^{49}$

Ego Gaufridus archid(iaconus) ${ }^{50}$

Ego Osmundus archi(diaconus) $)^{51}$

Ego B(er)nardus abbas Montis S(ancti) Mich(aelis) ${ }^{52}$

Ego Frat(er)nus abbas S(ancti) Audoeni ${ }^{33}$

Ego Rad(ulfus) abbas de Cruce S(ancti) Lerifridi ${ }^{54}$

Ego Fulb(er)tus archidiaconus ${ }^{55}$

Ego Hugo archid(iaconus) $)^{56}$

Ego Egidius archid(iaconus) ${ }^{57}$

4 - Inspeximus issued by either Richard of Gloucester or Robert des Ablèges, bishop of Bayeux, of the foundation of the deanship of Avranches.

A. Original lost.

B. Bibl. mun. d'Avranches, ms 206, fol. 34V, $\mathrm{n}^{\circ} \mathrm{XLI}$, under the rubric: "Littera episcopi Baiocen(sis) super decanatu ecclesie Abr(incensis)".

Ptd. Lebrun, "Le temporel [diplôme]...", p. 62.

44. Sic B, corr. de

45. Sic B, corr. vestre.

46. Sic B, corr. vestre.

47. Sic B, corr. vestre.

48. Arnulf, bishop of Lisieux, 1141-1181.

49. Waleran, dean of Rouen, c. 1137-c. 1146.

50. Geoffrey, archdeacon of Rouen, 1133-1148.

51. Osmund II, archdeacon of Rouen, $1111 \times 1115-1158$.

52. Bernard, abbot of Mont-Saint-Michel, 1131-1149.

53. Fraternus, abbot of Saint-Ouen de Rouen, after 12 June $1141 \times$ before 1 Aug. 1142-1157.

54. Sic B, corr. Leufridi. Rodulf, abbot of La Croix-Saint-Leufroy, before 1143-after 1158 .

55. Fulbert III, archdeacon of Rouen, c. 1124-c. 1158.

56. Either Hugh de Fréuville, archdeacon of Rouen, c. 1138-c. 1158, or Hugh de Lingèvres, archdeacon of Avranches, 1142.

57. Giles, archdeacon of Rouen, 1138-1170. 
Note. The two dates assigned to this charter refer either to the episcopate of Richard of Gloucester or of Robert des Ablèges. The inspeximus of the abbot of Lessay was made at sometime between c. $1321 \times$ c. 1337 .

$1135 \times 1142$ or $1206 \times 1231$

$\mathrm{B}$

Nos vero R. Dei sustinencia Baioc(ensis) episcopus originalia predictorum Hugonis Rothom(agensis) archiepiscopi et Ric(ardi) Abrinc(ensis) episcopi, sigillis suis munita, que hic verbo ad verbum fideliter sunt transcripta diligenter inspeximus et legimus ad testimonium et veritatem hujus veritatis sigillum nostrum facientes apponi. Similiter nos Guill(elmu)s ${ }^{58}$ decanus et capitulum Baioc(ensis) ecclesie ipsa originalia cum sigillis verbo ad verbum fideliter hic transcripta diligenter inspeximus et audivimus, sigillum nostrum ad hujus veritatis testimonium apponentes. Similiter nos conventus Sancti Laudi, dyocesis Constanc(iensis), ipsa originalia cum sigillis verbo ad verbum fideliter hic transcripta diligenter inspeximus et audivimus, sigillum nostrum ad hujus veritatem testimonium apponentes. Similiter nos Silvester ${ }^{59}$ abbas et conventus Sancte Trinitatis Exaquii, ipsa originalia cum sigillis verbo ad verbum fideliter hic transcripta diligenter inspeximus et audivimus, sigillum capituli nostri ad hujus veritatis testimonium apponentes.

\section{5 - Confirmation of Hasculf de Subligny, of the donation of Toi to the deanship of Avranches.}

A. Original lost.

B. Bibl. mun. d'Avranches, ms 206, fol. 34v, $\mathrm{n}^{\circ}$ XLII, under the rubric: "De donatione decime de Toy".

Ptd. Lebrun, "Le temporel [diplôme]...", p. 62.

Note. This charter must have been issued after 1162, since it refers to Rolland, dean of Avranches (who first appears on 8 April of that year), but before Hasculf's death in 1169.

$$
1162 \times 1169
$$

$\mathrm{B}$

Notum sit omnibus tam presentibus quam futuris quod ego Hasculphus de Suligneio duas garbas de Toi quas Ric(ardus) frater meus, pie recordacionis episcopus, habuerat dum decanus esset et, post eum, qui ei successit, Hugo de

58. Either a previously unidentified dean named William operating during the episcopate of Richard of Gloucester, bishop of Bayeux, 1135-1142, or William IV, dean of Bayeux, 1213-1226.

59. Sylvester, abbot of Lessay, c. 1321-c. 1337. 
Musca $^{60}$, Rollando ${ }^{61}$ decano et omnibus decanis Abrinc(ensibus), imperpetuam elemosinam concessi et donationem meam presente capitulo super altare posui. Quam, ut firmior esset, sigilli mei impressione roboravi et etiam singulorum domini episcopi et capituli Abr(incensis) munimine roborari volui. Affuerunt autem huic donationi laici plures: Ran(ulfus) de $P(r a)$ eres $^{62}$, Alanus de Insula, Petrus de V(er)duno ${ }^{63}$, Guill(elmu)s filius Aug(er)i et multi alii.

60. Hugh de la Mouche, dean of Avranches, 1143-1160.

61. Rolland, dean of Avranches, 8 April 1162-c. 1187/8.

62. Presles, dép. Calvados, cant. Vassy. Rannulf was probably the son of Matthew de Presles and his wife Beatrice, a was a tenant of the earls of Chester.

63. The land of Verdun is located in Vessey, dép. Manche, cant. Pontorson.

http://www.unicaen.fr/mrsh/craham/revue/tabularia/print.php?dossier=sources\&file=11allen.xml 